Liudmyla Mikhnevych,

Ph.D., Associate Professor, Kyiv National Economics University named after Vadym Hetman, Ukraine

Victor Marchenko,

Ph.D., Professor, Kyiv National Economics University named after Vadym Hetman, Ukraine

Petur Hristov,

Dr. Sc., Professor, Varna Free University "Chernorizets Hrabar", Bulgaria

Aleksandra Kuzior,

Ph.D., Habilitated Doctor of Humanities, Professor, Silesian University of Technology, Poland

\title{
CONCEPTUAL RELATIONSHIPS BETWEEN COUNTRY IMAGE AND ECONOMIC SECURITY
}

Abstract. The paper deals with the analysis of the linking between country image and level of economic security. The studies confirmed that ongoing tendency on world competitiveness justified considering direct and indirect dimensions which influence on the country's economic security. The authors generalised the factors which affected the economic security of the country. The finding proved that one of the significant indirect parameters is the country image. The authors analysed and summarised the most appropriate definitions of country brand and image. The authors analysed the frequency of country brand and image in the scientific paper. The paper aimed to identify the scientific clusters on the investigation of economic security and the country's brand. The study used the bibliometric analysis using software VOSviewer, Web of Science and Scopus Tools Analysis. The data of analysis was obtained from the scientific database Scopus and Web of Science for 1991-2019 years. For the analysis, the papers were selected as the criteria as follows: English language; published for 1991-2019 years; contained the keywords brand, image, county and security. The results of the analysis proved that the paper which used the term "country image" is more than "country brand" in Scopus and Web of Science. The findings from the Web of Science and Scopus Tools Analysis confirm the hypothesis on the increasing tendency of publishing activities papers which focused on the analysis of security and country's image. The visualising of co-authorship by country allowed identifying that the 50\% papers published by the scientists with the American, Ukrainian, Canadian, Spanish and Russian affiliations. The VOSviewer results allowed identifying two significant scientific clusters as follows: country image and economic security. Besides, between the two most significant cluster were as mediators: governance, nation branding, developing countries and environment. Besides, analysing the new publication for 2015-2019 years, the most cited papers on economic security connected with analysis not only quantitively economic parameters but also with political, sustainable development and country's image. The bibliometric analysis formed the background for checking the casual relationship between image and economic security of the country.

Keywords: bibliometric analysis, brand, brand management, country brand, VOSviewer.

Introduction. The intensification of the world competitiveness provokes to consider not only direct economic issues but also the qualitative dimensions such as country brand/image towards developing the government policy on the economic development strategy of the country. Besides, the results of the analysis proved that country which occupied the first position on the Global Sustainability Competitiveness Index also had the leading positions on the Country Brand Index.

Thus, the first five places on the Country Brand Index among EU countries were occupied by the countries with a high-income economy and stable level of economic security. At the same time, in 2017, the rating of the Global Competitiveness Index showed the other group of the country took the first places: Sweden, Finland, Denmark, Ireland and Austria. The second indicator which allowed estimating of the country's security was GDP per capita. Considering the data, the first places were occupied by the countries as follows: Luxemburg, Ireland, Netherland, Austria, Denmark, Germany. Unfortunately, Ukraine occupied the last places by all analysed indicators which confirmed by the imbalances in political and economic areas. The compilation data of the selected indexes showed in Table 1.

Cite as: Mikhnevych, L., Marchenko, V. Hristov, P., \& Kuzior, A. (2020). Conceptual Relationships Between Country Image and Economic Security. Marketing and Management of Innovations, 1, 285-293. https://doi.org/10.21272/mmi.2020.1-24 
L. Mikhnevych, V. Marchenko, P. Hristov, A. Kuzior. Conceptual Relationships Between Country Image and Economic Security

Table 1. The generalisation data of the GDP, Nations Brand Index and Global Sustainability Competitiveness Indexes for 2012-2017 years

\begin{tabular}{|c|c|}
\hline Index & Dynamic \\
\hline $\begin{array}{l}\text { Nations Brand } \\
\text { Index }\end{array}$ & 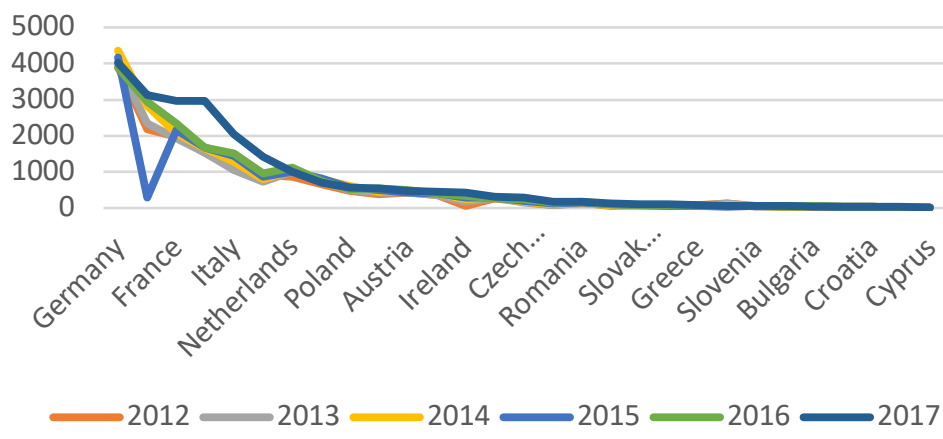 \\
\hline GDP & 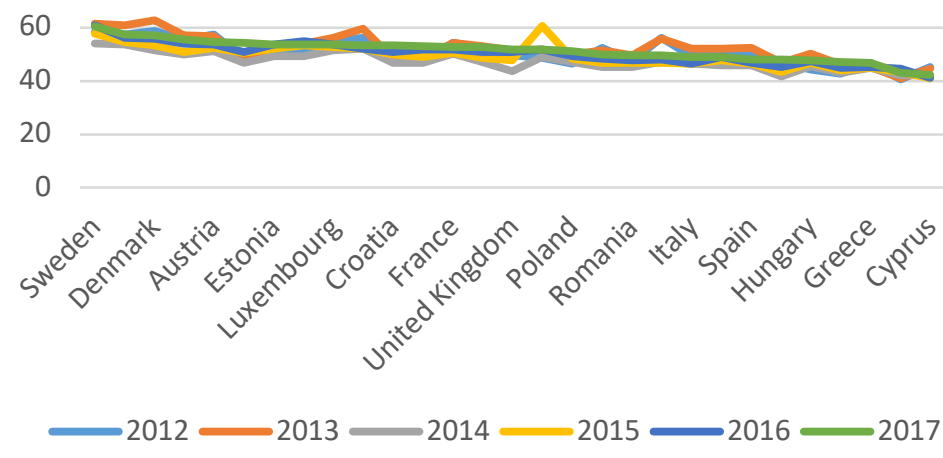 \\
\hline $\begin{array}{c}\text { Global } \\
\text { Sustainability } \\
\text { Competitiveness } \\
\text { Index }\end{array}$ & 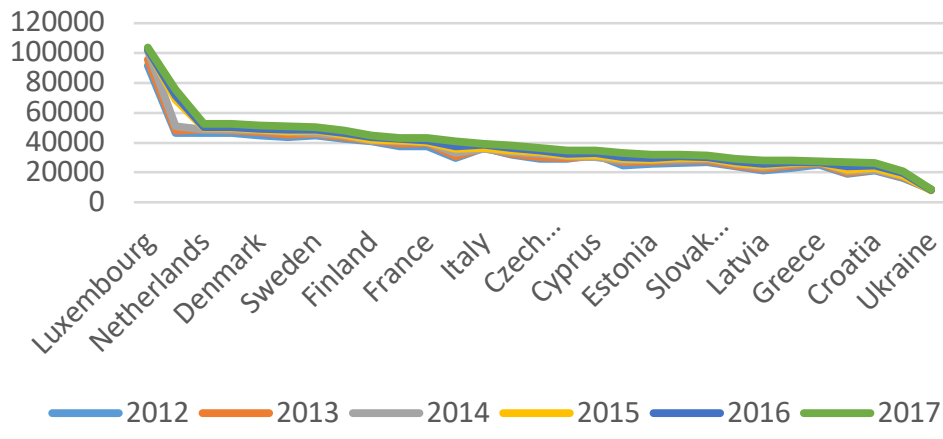 \\
\hline
\end{tabular}

Sources: developed by authors using (Nation, 2019; World, 2019; Solability, 2019)

The findings confirmed that on the country in the first place on GDP was not at the first place on Country Brand or the Global Competitiveness Indexed. In this case, it is necessary to analyse the main direct and indirect dimensions which influence on the country's competitiveness and economic security. 

Security

The paper aimed to analyses on the scientific background on the issue mentioned above toward allocating the scientific schools in the world on economic security, country brand and image.

Literature Review. The results of the analysis of the scientific background proved that the scientists analysed economic security from the different points of views allocating different types of dimensions. The authors in the paper (Vasylieva et al., 2017) proved that the level of education affected on economic security and image of the country.

The scientist in the paper (Vasilieva et al., 2017) confirmed that transparency influenced the country stability and brand. In this case, the transparency was the mediator between investors the and country. Besides, other scientists in the papers (Lyulyov et al., 2017; Bilan et al., 2019a; Ibragimov et al., 2019a; Pimonenko, 2018; Rekunenko et al., 2019; Seguino et al., 2010) confirmed the hypothesis on casual relationship between investment climate and country image. The Chinese scientists Chen J., Zhu X. and Zhong M. In the paper (Chen et al., 2019) using VAR analysis confirmed the statistically significant impact of the financial stability on the economic security of the country.

The group of the scientists (Bauman et al., 2000; Ibragimov et al., 2019a; Vasylieva et al., 2019; Williams et al., 1990) analysed economic security from social points of views. The authors (Bilan et al., 2019; Cheddad et al., 2010; GrenÄÃ kovÃ et al., 2019) confirmed on the economic security influenced the factors as follows: digitalisation; industry 4.0; research and development in the countries.

The group of the scientists in the papers (Bilan et al., 2019d; Bilan et al., 2019e; Bloom et al., 2015; Inglehart et al., 1994; Jun et al., 2009; Luechinger et al., 2010; Milberg et al., 2011; Partha et al., 1994) analysed the macroeconomic stability and governance efficiency as an indicator of the economic security. Besides, the scientists Kendall G. E., Nguyen H. and Ong R. (2019) proved the linking between sustainable development, economic security and social well-being. The British author Haagh (2019) confirmed the statistically significant impact of income security reforms on governance efficiency and the country's stability.

Noted, that in the papers (Bilan et al., 2019c; Lyulyov et al., 2018) the scientist used the model Fetcher for brand assessments and analysed the causal relationship between macroeconomic stability and efficiency of the country brand management. Despite robust scientific background on the analysing of the economic security from the different points of views, the issues on linking country image and economic security have not investigated yet.

Methodology and research methods. The central hypothesis of the paper was identifying the scientific background on the analyses of the economic security and countries image and brand. The study checked the hypothesis as follows: brand".

$\mathrm{HO}$ : the most paper in Web of Science and Scopus used the definition "country image" than "country

$\mathrm{H} 1$ : the scientists mostly analysed economic security from the economic and political points of views.

$\mathrm{H} 2$ : linking between scientific clusters which focused on economic security and country image and brand.

The study conducted by the following steps:

1. Identifying the keywords for analysis.

2. Selectin paper in Scopus and Web of Science.

3. Applying the classification criteria: years 1991-2017, English language.

4. Eliminating the duplicate of the papers.

5. Co-authors', co-occurrence and cross countries analysis.

6. Visualising and interpretation of the data.

For the first, the second and the third stages, the Scopus and Web of Science Tools analyses were used, which allowed identifying the central tendency and relevant keywords on research problems. 
L. Mikhnevych, V. Marchenko, P. Hristov, A. Kuzior. Conceptual Relationships Between Country Image and Economic Security

Besides, that instrument allowed analysed the financing source of research and identifying the most cited scientists and paper on the investigated issues.

The fourth step was realised by Microsoft Excel Office. The co-authors', co-occurrence and cross countries analysis and visualising and interpretation of the data were done by software VOSviewer. Its application allowed developing a map of scientific clusters and explained the links between scientific schools.

Results. The results of the analysis of the most using definition "country brand" or "country image" confirmed that scientists prefer to use the "country image" in their investigation. Thus, Scopus contained 120 publications and Web of Science - 101 publications with keywords "country brand". However, the country image was used by 551 papers in Scopus and 446 - Web of Science. The comparison analysis was showed in Table 2.

Table 2. Comparison analysis of the papers with keywords "country brand" and "country image" in Scopus and Web of Science

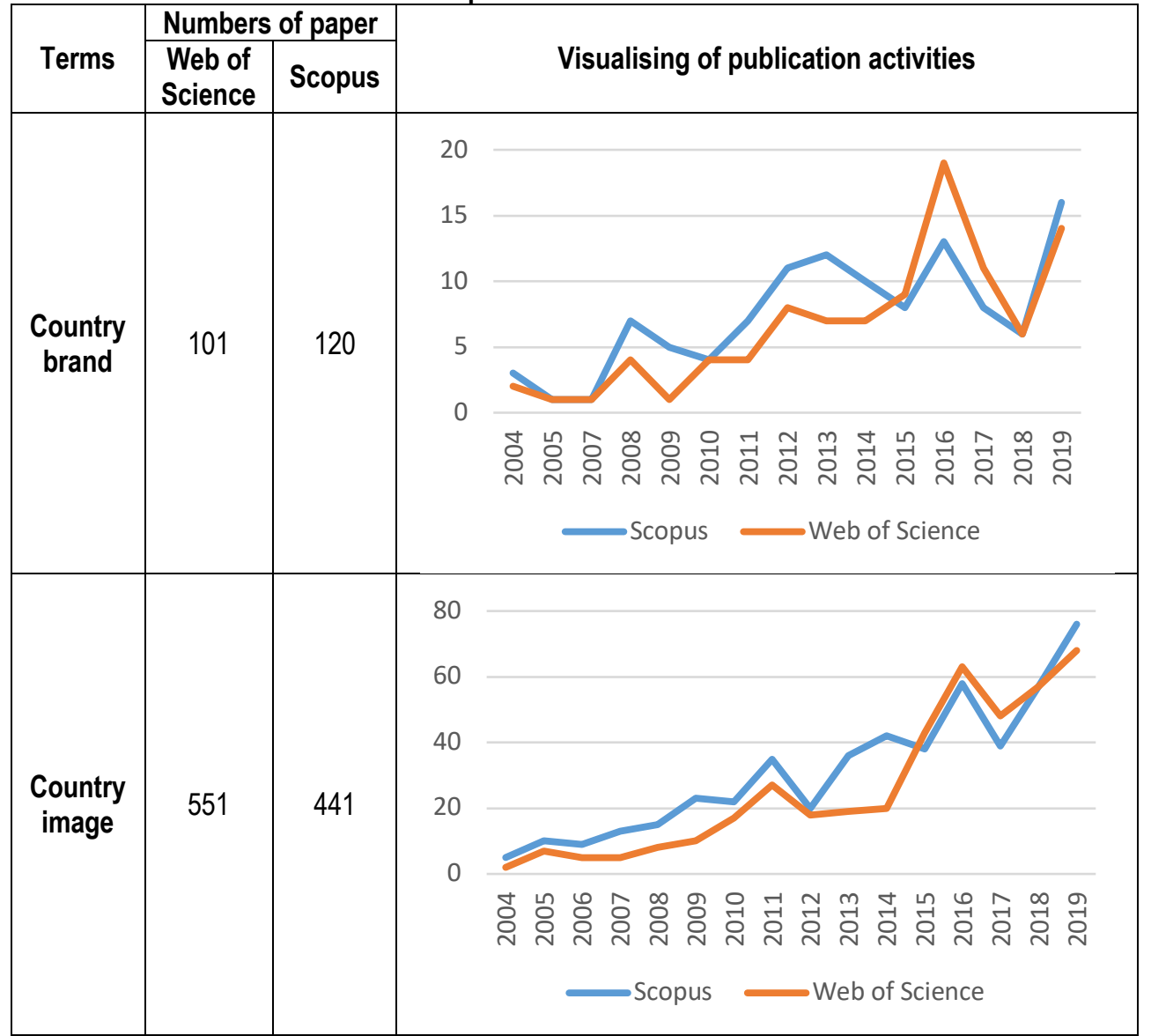

Sources: developed by authors using Web of Science and Scopus Tools Analyses

The findings proved the increasing tendency of the papers, which focused on the analysis of country brand and image. Besides, the results confirmed the $\mathrm{HO}$ : the most paper in Web of Science and Scopus 

Security

used the definition "country image" than "country brand".

The results of visualising data showed (Figure 1) that country image analyses from a few points of views. Thus, the most significant clusters connected with the analysis brand from the traditional marketing concept: distribution, marketing strategy, the brand of origin, country of origin.

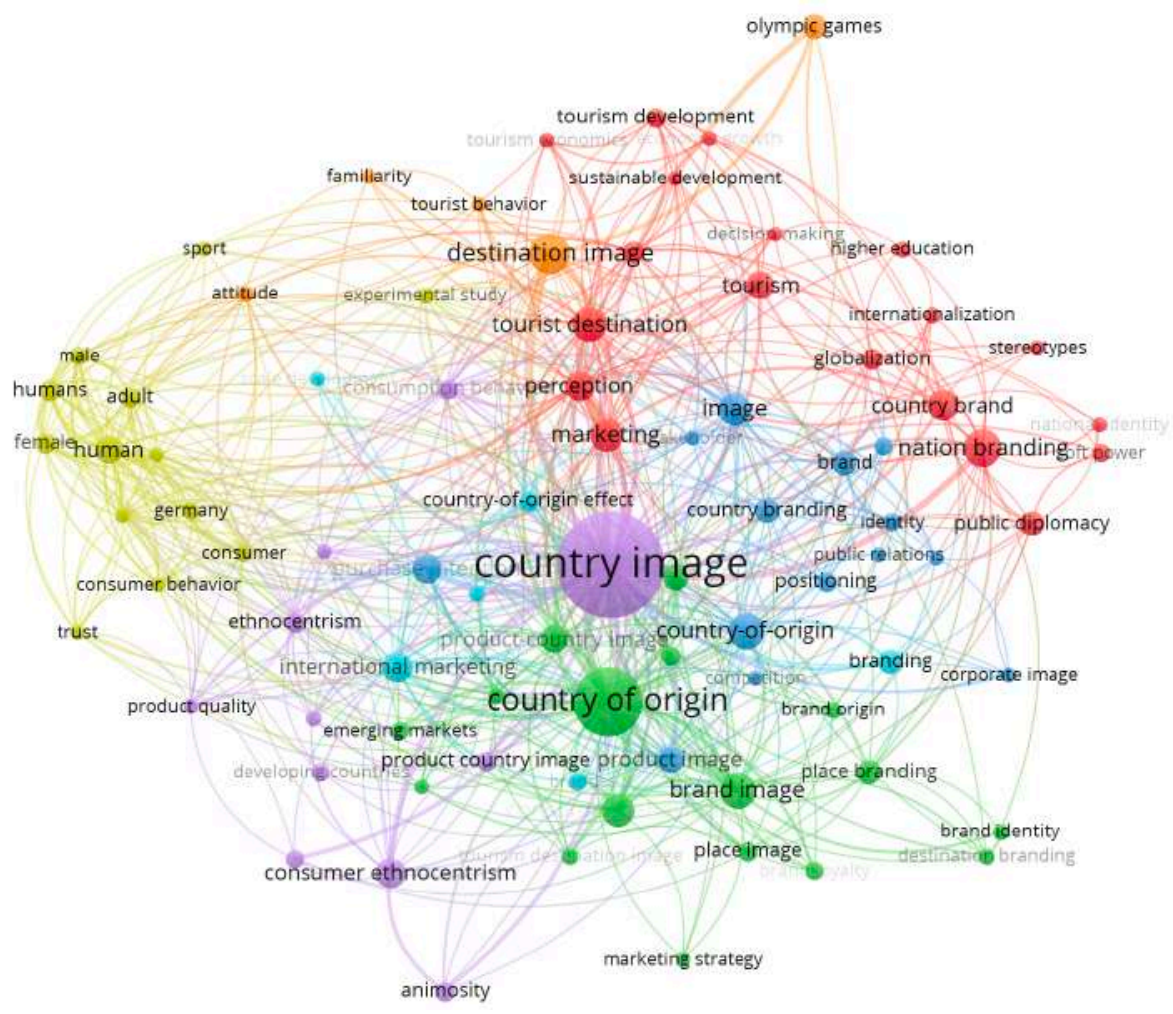

Figure 1. Visualising map co-occurrence analysis of papers with the keywords "country image"

Sources: developed by authors using VOSviewer. and "country brand."

The second clusters devoted to the analysis of brand as a touristic feature. In that cluster, the paper focused on the analyses of tourism development and destination, sustainability. The third clusters contained papers which focused on the globalisation, competitiveness, nation branding.

For the checking hypothesis on ways to analyse the economic security or economic stability, the 4000 papers were chosen. After excluding duplicate, the 3000 papers were left for further analysis. Thus, the findings showed that the numbers of the published papers rapidly increased that during and after the financial crisis.

Besides, most papers were published by the authors with affiliations as follows: United States, Russian Federation, United Kingdom, China, Canada, Australia, India and Ukraine. Table 3 summarised findings of analysis papers on economic security and stability. 
L. Mikhnevych, V. Marchenko, P. Hristov, A. Kuzior. Conceptual Relationships Between Country Image and Economic Security

Table 3. Comparison analysis of the papers with keywords "economic security" or "economic stability" in Scopus and Web of Science

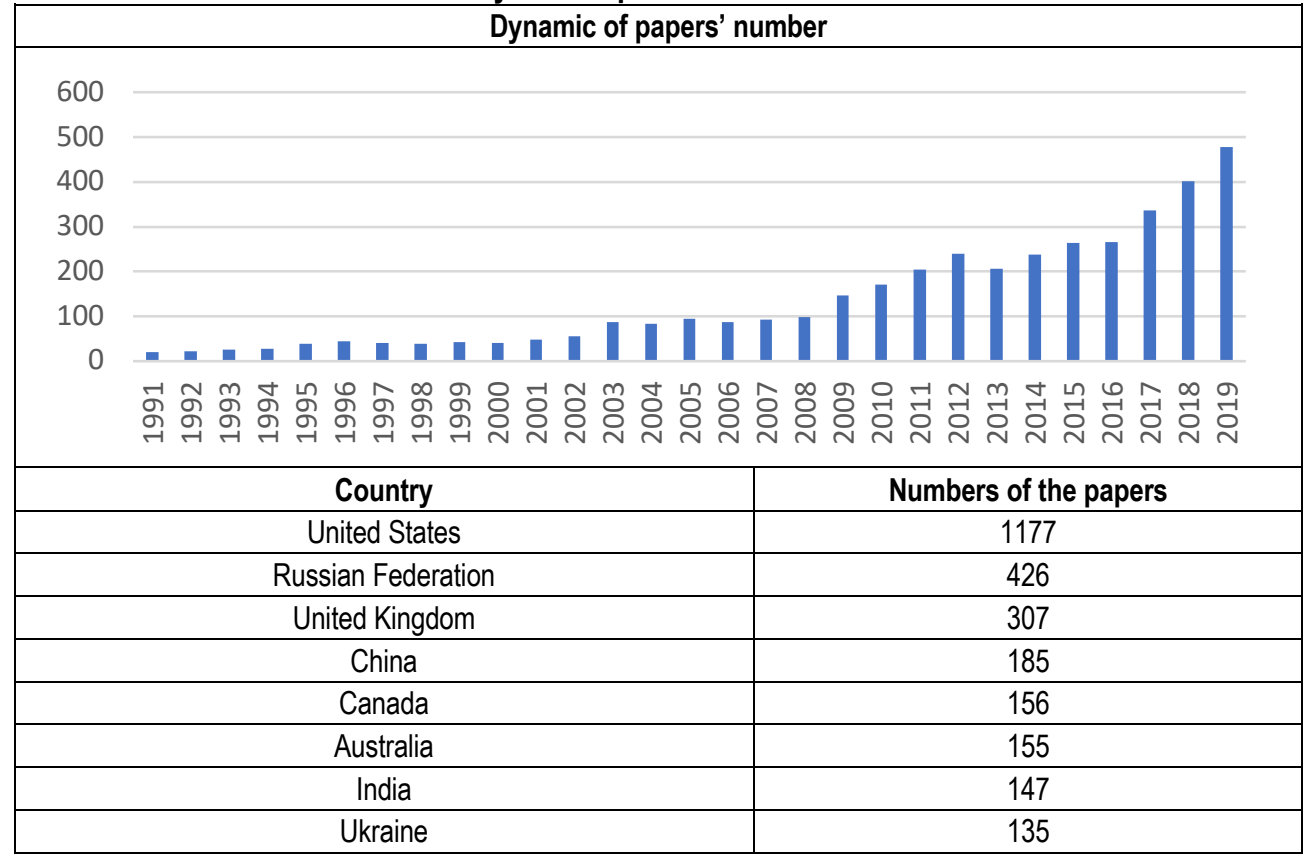

Sources: developed by authors using Web of Science and Scopus

At the next stage of the analysis, the following keywords were inserted in searching: security, stability, brand and image. After the selection and eliminating the duplicate, the 10000 papers were chosen for the further visualising of the finding of co-authors', co-occurrence and cross countries analysis. Figure 2 and 3 contained the results of the analysis.

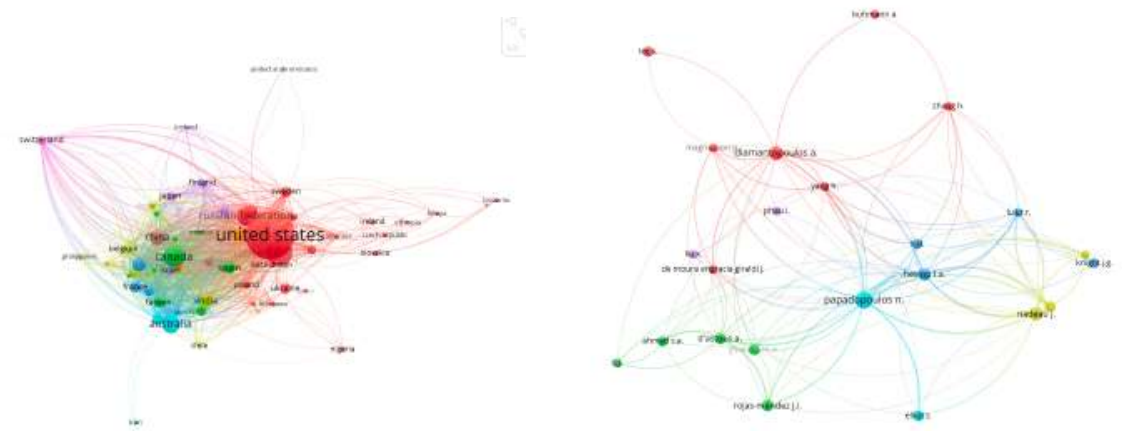

Figure 2. Visualising map of co-authors' and cross countries analysis of the papers with keywords "country image", "country brand "economic security", "economic stability" in Scopus Sources: developed by authors using VOSviewer. and Web of Science 


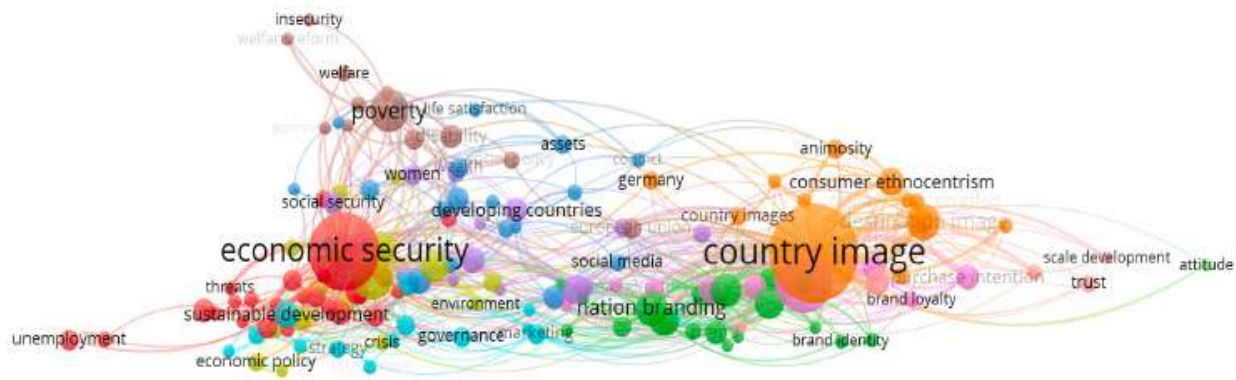

Figure 3. Visualising map of co-occurrence analysis of the papers with keywords "country image", "country brand "economic security", "economic stability" in Scopus and Web of Science Sources: developed by authors using VOSviewer.

The findings in the previous stage confirmed results that the most papers on country image", "country brand "economic security", "economic stability" was published in USA, Ukraine, Canada, Spain and Russian Federation. At the same time, only six papers were published in the United Arab Emirates, and less in Iran, Hungary and Iceland.

The co-occurrence analysis showed that significant big clusters could be identified: country image and economic security. The linking between that clusters were provided by the intermediaries' clusters as follows: governance, nation branding, developing countries and environment. Such results confirmed the $\mathrm{H} 2$ : linking between scientific clusters which focused on economic security and country image and brand. At the same time, the linking was not direct. Besides, analysing the new publication for 2015-2019 years, the most cited papers on economic security connected with analysis not only quantitively economic parameters but also with political, sustainable development and country's image.

Conclusions. The results of the analysis confirmed all research hypothesis on: the most paper in Web of Science and Scopus used the definition "country image" than "country brand"; the scientists mostly analysed economic security from the economic and political points of views; linking between scientific clusters which focused on economic security and country image and brand. At the same time, most papers on economic security published by the authors in countries which mostly suffered from the financial crisis. From the other side, the new directions of economic security analysis appeared in the country with a stable economic and political climate. Thus, the findings allowed identifying the new scientific clusters such as: political, sustainable development and country's image. In this case, the bibliometric analysis formed the background for checking the casual relationship between image and economic security of the country.

Author Contributions: conceptualisation, methodology, investigation, visualisation L. M, V. M., PH and A. K.

\section{References}

Bauman, Z. (2000). Social issues of law and order. British Journal of Criminology, 40(2), 205-221. [Google Scholar] [CrossRef]

Bilan, Y., Brychko, M., Buriak, A., \& Vasilyeva, T. (2019a). Financial, business and trust cycles: The issues of synchronisation. Zbornik Radova Ekonomskog Fakultet Au Rijeci, 37(1), 113-138. [Google Scholar] [CrossRef]

Bilan, Y., Đšuzmenko, Đ., \& Boiko, A. (2019b). Research on the impact of industry 4.0 on entrepreneurship in various countries worldwide. In Proceedings of the 33rd International Business Information Management Association Conference, IBIMA 2019: 
Education Excellence and Innovation Management through Vision 2020 (pp. 2373-2384). International Business Information Management Association, IBIMA.

Bilan, Y., Lyeonov, S., Lyulyov, O., \& Pimonenko, T. (2019c). Brand management and macroeconomic stability of the country. Polish Journal of Management Studies, 19(2), 61-74. [Google Scholar] [CrossRef]

Bilan, Y., Raišienè, A. G., Vasilyeva, T., Lyulyov, O., \& Pimonenko, T. (2019d). Public Governance efficiency and macroeconomic stability: Examining convergence of social and political determinants. Public Policy and Administration, 18(2), 241255. [Google Scholar] [CrossRef]

Bilan, Y., Vasilyeva, T., Lyulyov, O., \& Pimonenko, T. (2019e). EU vector of Ukraine development: Linking between macroeconomic stability and social progress. International Journal of Business and Society, 20(2), 433-450. [Google Scholar]

Bloom, D. E., Chatterji, S., Kowal, P., Lloyd-Sherlock, P., McKee, M., Rechel, B., . . . Smith, J. P. (2015). Macroeconomic implications of population ageing and selected policy responses. The Lancet, 385(9968), 649-657. [Google Scholar] [CrossRef]

Cheddad, A., Condell, J., Curran, K., \& Mc Kevitt, P. (2010). Digital image steganography: Survey and analysis of current methods. Signal Processing, 90(3), 727-752. [Google Scholar] [CrossRef]

Chen, J., Zhu, X., \& Zhong, M. (2019). Nonlinear effects of financial factors on fluctuations in nonferrous metals prices: A markov-switching VAR analysis. Resources Policy, 61, 489-500. [Google Scholar] [CrossRef]

GrenÄÃ kov $\tilde{A}_{i}$, A., Bilan, Y., Samusevych, Y., \& Vysochyna, A. (2019). Drivers and inhibitors of entrepreneurship development in central and eastern European countries. In Proceedings of the 33rd International Business Information Management Association Conference, IBIMA 2019: Education Excellence and Innovation Management through Vision 2020 (pp. 2536-2547). International Business Information Management Association, IBIMA.

Haagh, L. (2019). The political economy of governance capacity and institutional change: The case of basic income security reform in european welfare states. Social Policy and Society, 18(2), 243-263. [Google Scholar] [CrossRef]

Ibragimov, Z., Lyeonov, S., \& Pimonenko, T. (2019a). Green investing for SDGS: EU experience for developing countries. Economic and Social Development: Book of Proceedings, 867-876. [Google Scholar]

Ibragimov, Z., Vasylieva, T., \& Lyulyov, O. (2019b). The national economy competitiveness: effect of macroeconomic stability, renewable energy on economic growth. Economic and Social Development: Book of Proceedings, 877-886. [Google Scholar] Inglehart, R., \& Abramson, P. R. (1994). Economic security and value change. American Political Science Review, 88(2), $336-$ 354. [Google Scholar] [CrossRef]

Jun, E., Kim, W., \& Chang, S. H. (2009). The analysis of security cost for different energy sources. Applied Energy, 86(10), 1894-1901. [Google Scholar] [CrossRef]

Kendall, G. E., Nguyen, H., \& Ong, R. (2019). The association between income, wealth, economic security perception, and health: A longitudinal australian study. Health Sociology Review, 28(1), 20-38. [Google Scholar] [CrossRef]

Kuzior, A., Kwilinski, A., Tkachenko, V. \& Tkachenko, V. (2019). Sustainable development of organisations based on the combinatorial model of artificial intelligence. Entrepreneurship and Sustainability Issues, 7(2), 1353-1376. [Google Scholar [CrossRef]

Luechinger, S., Meier, S., \& Stutzer, A. (2010). Why does unemployment hurt the employed?: Evidence from the life satisfaction gap between the public and the private sector. Journal of Human Resources, 45(4), 998-1045. [Google Scholar] [CrossRef]

Lyulyov, O. V., \& Pimonenko, T. V. (2017). Lotka-Volterra model as an instrument of the investment and innovative processes stability analysis. Marketing and Management of Innovations, (1), 159-169. [CrossRef]

Lyulyov, O., Chygryn, O., \& Pimonenko, T. (2018). National brand as a marketing determinant of macroeconomic stability. Marketing and Management of Innovations, (3), 142-152. [Google Scholar] [CrossRef]

Milberg, W., \& Winkler, D. (2011). Economic and social upgrading in global production networks: Problems of theory and measurement. International Labour Review, 150(3-4), 341-365. [CrossRef]

Nation Brands 2019. (2019). The annual report on the most valuable and strongest nation brands. Retrieved from: https://brandirectory.com/rankings/nation-brands/

Osberg, L., \& Sharpe, A. (2002). An index of economic well-being for selected OECD countries. Review of Income and Wealth, 48(3), 291-316. [Google Scholar] [CrossRef]

Partha, D., \& David, P. A. (1994). Toward a new economics of science. Research Policy, 23(5), 487-521. [Google Scholar] [CrossRef

Pimonenko, T. (2018). Ukrainian Perspectives for Developing Green Investment Market: EU Experience. Economics and Region, 4(71), 35-45. [Google Scholar]

Rekunenko, I. I., Hrytsenko, L. L., Boiarko, I. M., \& Kostyrko, R. A. (2019). Financial debt market in the system of indicators of development of the economy of the country. Financial and Credit Activity: Problems of Theory and Practice, 2(29), 430-439. [CrossRef]

Seguino, S. (2010). The global economic crisis, its gender and ethnic implications, and policy responses. Gender and Development, 18(2), 179-199. [Google Scholar] [CrossRef]

Shvindina, H. (2019). Coopetition as an emerging trend in research: Perspectives for safety \& security. Safety, 5(3). [Google Scholar] [CrossRef]

Solability. (2019). The Global Sustainability Competitiveness Index. Retrieved from: http://solability.com/the-global-sustainablecompetitiveness-index/the-index 
Tkachenko, V., Kwilinski, A., Kaminska, B., Tkachenko, I., \& Puzyrova, P. (2019). Development and Effectiveness of Financial Potential Management of Enterprises in Modern Conditions. Financial and credit activity: problems of theory and practice, 3(30), 8594. [Google Scholar] [CrossRef]

Tkachenko, V., Kwilinski, A., Klymchuk, M., \& Tkachenko, I. (2019). The Economic-Mathematical Development of Buildings Construction Model Optimization on the Basis of Digital Economy. Management Systems in Production Engineering, 27(2), 119-123. [Google Scholar] [CrossRef]

Vasilieva, T., Lieonov, S., Makarenko, I., \& Sirkovska, N. (2017). Sustainability information disclosure as an instrument of marketing communication with stakeholders: markets, social and economic aspects. Marketing and Management of Innovations, (4), 350-357. [Google Scholar] [CrossRef]

Vasylieva, T. A., Lieonov, S. V., Petrushenko, Yu. M., \& Vorontsova, A. S. (2017). Investments in the system of lifelong education as an effective factor of socio-economic development. Financial and Credit Activity: Problems of Theory and Practice, 2(23), 426436. [CrossRef]

Vasylieva, T., Lyulyov, O., Bilan, Y., \& Streimikiene, D. (2019). Sustainable economic development and greenhouse gas emissions: The dynamic impact of renewable energy consumption, GDP, and corruption. Energies, 12(17), 3289. [Google Scholar] [CrossRef]

Williams, A. S., \& Jobes, P. C. (1990). Economic and quality-of-life considerations in urban-rural migration. Journal of Rural Studies, 6(2), 187-194. [CrossRef]

World Data Bank. (2019). Retrieved from: https://data.worldbank.org

Людмила Міхневич, к.ю.н., доцент, Київський національний економічний університет імені Вадима Гетьмана (Ураїна);

Віктор Марченко, К.ю.н., доцент, Київський національний економічний університет імені Вадима Гетьмана (Ураїна);

Петер Христов, Dr. Sc., профеесор, Грабар Варненський вільний університету «Чорноризець Грабар» (Болгарія);

Александра Кужьор, Ph.D., Сілезький технологічний університет (Польща).

Концептуальні засади взаємозалежності між іміджем та економічною безпекою країни

У статті проаналізовано тенденцію наукових публікацій, що досліджують питання взаємозв'язку між іміджем та рівнем економічної безпеки країни. Авторами проаналізовано та узагальнено наукові підходи щодо визначення детермінантів, які впливають на рівень економічної безпеки країни. При цьому встановлено, що одним із значимих фокторів, що потребує врахування при оцінюванні рівня економічної безпеки - імідж країни на світовому ринку. Метою статті $\epsilon$ аналіз та виокремлення наукових кластерів, що досліджують питання економічної безпеки та іміджу країни. У дослідженні проведено бібліометричний аналіз з використанням програмного забезпечення VOSviewer, iнструментів Web of Science та Scopus Tools Analysis. Вибірку даних для аналізу сформовано з наукометричних баз даних Scopus та Web of Science за 1991-2019 роки. Основними критеріями відбору наукових публікацій були: мова статті - англійська; опубліковані за 1991-2019 роки; містили ключові слова бренд, імідж, стабільність та безпека. Авторами узагальненого частоту використання термінів «бренд країни» та «імідж країни» у наукових публікаціях вчених. Встановлено, що термін «імідж країни» частіше використовується вченими ніж «бренд країни» у наукових публікаціях, що індексуються наукометричними базами даних Scopus та Web of Science. Результати аналізу з використанням інструментів Web of Science та Scopus Tools Analysis підтвердили гіпотезу про зростаючу тенденцію публікацій, що досліджують питання економічної безпеки та іміджу країни. Візуалізація результатів аналізу у розрізі країн дозволила визначити, що 50\% робіт, опубліковано вченими з американською, українською, канадською, іспанською та російською афіляціями. Результати бібліометричного аналізу з використанням програмного забезпечення VOSviewer дозволили виокремити два наукових кпастери: імідж країни та економічна безпека. Крім того, між двома найбільшими кластерами є такі кластери-посередники як: управління; брендинг націй; країни, що розвиваються; сталий розвиток. Крім того, аналіз публікаційної активності за 2015-2019 роки дозволив визначити тенденцію зростання кількості публікації, що досліджують економічну безпеку країни не лише на основі оцінювання економічних параметрів розвитку країни, а й оцінювання політичної стабільності, сталого розвитку та іміджу країни. Результати бібліометричного аналізу сформували передумови подальших досліджень щодо емпіричного оцінювання взаємозв'язків між іміджем та економічною безпекою країни.

Ключові слова: бібліометричний аналіз, бренд, управління брендом, бренд країни, VOSviewer.

Manuscript received: 05.12.2019.

(C) The author(s) 2020. This article is published with open access at Sumy State University. 